\title{
Paddock shape effects on grazing behavior and efficiency in sheep
}

\author{
AgOSTINO SEVI, ANTONIO MUSCIO, DELIA DANTONE, VINCENZO IASCONE, AND FRANCESCO \\ D'EMILIO
}

Authors are associate professor, professor, technician, scholarship holder with Institute of Food Production and Preparation, Agriculture Faculty, Via Napoli, 25-71100 Foggia (Italy) and scholarship holder with Research Institute for Fodder Crops, Via Napoli, 52, 71100 Foggia (Italy), respectively.

\begin{abstract}
Two grazing trials were conducted during early winter (December 1996-January 1997) and spring (April-May 1997) to evaluate the effect of shape of pasture on forage use and behavior of grazing sheep (Ovis aries). Two treatments were tested, square and rectangular paddock, with 2 replicates for each treatment of 9 ewes each. Groups were homogeneous for age and weight. Paddock size furnished $10 \mathrm{~m}^{2}$ per sheep per day. Each paddock was divided into 8 equal plots to determine herbage intake and grazing efficiency along the boundary and in the middle of paddocks. The shape of paddock affected sheep grazing efficiency and herbage intake both in the winter and in the spring. Because of a greater amount of herbage destroyed within boundary plots, the ewes in rectangular paddocks grazed less time, had lower herbage intake and used forage less efficiently than ewes in square paddocks. These results suggest that the shape of pasture can affect the behavior and herbage intake of sheep grazing in small paddocks and indicate that square paddocks should be used for research studies on sheep grazing behavior.
\end{abstract}

Key Words: diet choice, space pattern, grazing management

There is evidence that feeding behavior of grazing sheep (Ovis aries) is largely affected by environmental conditions (Arnold and Dudzinski 1978, Bueno and Ruckebusch 1979, Dudzinski and Arnold 1979), sward characteristics (Penning et al., 1994) and endogenous factors, such as physiological state (Penning et al. 1995), breed (Arnold 1975, Dudzinski and Arnold 1979) and previous experience (Olson et al., 1996). Because sheep do not use space at random (Hutson, 1984) and graze differently when they are put in rectangular compared to square paddocks (Lynch and Hedges, 1979), it is likely that paddock shape can influence forage use and feeding behaviour of sheep on pasture. Lange (1985) has shown that in a small paddock of high quality improved pasture the stocking intensity of various parts of the paddock varied from one-eighth to 8 times the paddock average stocking rate. In housed ewes, Sevi et al. (1996) found an effect of the shape of pen on space use, the square pens resulting in more uniform use of space than the circular and the triangular pens.

Sevi, corresponding author: telephone 0039-881-714544; Fax 0039-881740211, e-mail prodan.fgagr@isnet.it

Manuscript accepted 15 Jun. 2000.

\section{Resumen}

Se condujeron dos experimentos de apacentamiento durante inicios de invierno (Diciembre 1996 - Enero 1997) y primavera (Abril-Mayo 1997) para evaluar el efecto de la forma del potrero en el uso del forraje y el comportamiento de apacentamiento de los ovinos (Ovis aries). Se probaron dos tratamientos, potreros rectangulares y cuadrados. Se tuvieron 2 repeticiones por tratamiento de 9 borregas cada una, los grupos de borregas eran homogéneos en edad y peso. El tamaño del potrero suministró 10 $\mathrm{m}^{2}$ por borrega día-1. Cada potrero se dividió en 8 parcelas de igual tamaño para determinar el consumo de forraje $y$ la eficiencia de apacentamiento a lo largo de las orillas y en la parte central del potrero. La forma del potrero afectó la eficiencia de apacentamiento y el consumo de forraje tanto en invierno como primavera. Debido a que una mayor cantidad de forraje se destruyó dentro de los limites de las parcelas, las borregas en los potreros rectangulares apacentaron menos tiempo, tuvieron un consumo menor de forraje y utilizaron menos eficientemente el forraje que las borregas de los potreros cuadrados. Estos resultados sugieren que la forma del potrero puede afectar el comportamiento y consumo de forraje de los ovinos apacentando potreros pequeños e indican que los potreros cuadrados deben ser usados para estudios de investigación sobre el comportamiento de apacentamiento de ovinos.

Thus, research studies on sheep grazing behavior, which often use small flocks and paddocks with the expectation that the knowledge of factors controlling voluntary intake can be generalized, may be vitiated by overlooking the aspects of grazing behavior which are related to the utilization of space in small paddocks.

The present study was undertaken to investigate the effects of paddock shape on forage use by grazing sheep. Two trials were performed during the winter and the spring seasons to assess the impact of paddock shape on sheep feeding activity with respect to different climatic conditions and level of supplementation.

\section{Materials and Methods}

The experimental site was approximately 20 kilometers northwest of Foggia, Apulia, Southern Italy (latitude: $41^{\circ} 27^{\prime} 6^{\prime \prime}$ and longitude: $15^{\circ} 33^{\prime} 5^{\prime \prime}$ ), with an elevation of about 100 meters above sea level. The climate of this area is Mediterranean. Ambient temperatures, recorded at the meteorological station of 
the Capitanata Land-Reclamation Syndicate $(3.5 \mathrm{~km}$ away from the site of experiment), ranged from -5.8 to $18.5^{\circ} \mathrm{C}$ during the winter trial and from -3.5 to $33.8^{\circ} \mathrm{C}$ during the spring trial. Averages of relative humidity, sun radiation and wind speed were $79.4 \%, 55.4 \mathrm{~W} / \mathrm{m}^{2}$ and 2.2 $\mathrm{m} / \mathrm{sec}$ in winter and $61.1 \%, 215.8 \mathrm{~W} / \mathrm{m}^{2}$ and $2.9 \mathrm{~m} / \mathrm{sec}$ in spring.

The study pasture was composed of Graminaceae (Lolium spp., Bromus spp., Festuca spp.) and to a smaller extent of Cruciferae (Eruca sativa L.), Compositae (Carlina corymbosa L., Cirsium spp.) and Leguminosae (Medicago spp., Trifolium spp.). The above mentioned botanical families were nearly always distributed in very complex mixes.

Grazing trials were conducted during early winter (December 1996 to January 1997) and spring (April to May 1997) using dry Wurttenberg x Ile de France $\mathrm{x}$ Gentile di Puglia ewes. Both trials lasted 30 days and were divided into three, 10day grazing periods. Upon their arrival at the experimental site, the ewes were subjected to a 7-day acclimation period so they could become acquainted with their peers. During this period the sheep were allowed to graze similar pastures adjacent to the experimental pastures.

Two treatments were tested, square paddock (SP) vs rectangular paddock (RP) with 2 replicates of 9 ewes for each treatment at each season. The ewes of the experimental groups were homogeneous for age (3.5 years) and weight (approximately $65 \mathrm{~kg}$ ). Paddock size was $900 \mathrm{~m}^{2}$ (30m x 30m for square paddocks and $75 \mathrm{~m}$ $\mathrm{x} 12 \mathrm{~m}$ for rectangular paddocks) to maintain a constant area of $10 \mathrm{~m}^{2}$ per sheep per day. Daily forage allowance was 1.34 and $1.31 \mathrm{~kg} \mathrm{DM} / \mathrm{ewe} /$ day at the beginning of the winter trial and 1.95 and $1.91 \mathrm{~kg}$ $\mathrm{DM} / \mathrm{ewe}$ /day at the beginning of the spring trial for rectangular and square paddock treatments, respectively. Herbage composition was very similar among the experimental groups. Paddocks were contiguous with mesh-fence boundaries. The groups of animals were somewhat isolated visually by rows of almond trees. Paddock boundaries were about $50 \mathrm{~m}$ away from the road leading to the farm, so we consider that groups experienced the same amount of stimuli from the surrounding environment. Every day the ewes grazed from 0800 to 1600 hour in the winter and from 0900 to 1700 hour in the spring and spent the rest of the day in separate strawbedded pens. When the ewes returned to their own pens they were given vetch/oat hay $(1.0 \mathrm{~kg}$ in winter and $0.5 \mathrm{~kg}$ in spring

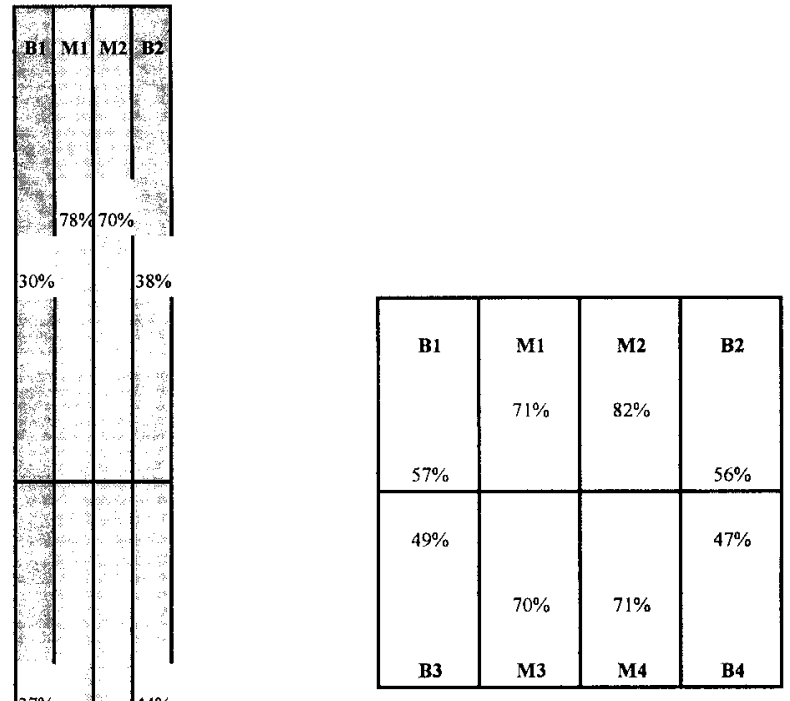

Square paddocks

Fig. 1. Paddock splitting in boundary (B) and middle (M) plots. Percentages are treatment mean utilization efficiency for each plot in square and rectangular paddocks (drawings are to scale of $1: 750$ ).

per head $)$ and wheat-bran $(0.25 \mathrm{~kg}$ per head in winter).

\section{Measurements}

Forage mass and composition were determined before and after each 10 day grazing period. To assess the utilization of boundaries compared to interior areas, paddocks were divided into 8 equal size plots (about $110 \mathrm{~m}^{2}$ each), 4 along the boundaries and 4 in the middle of paddocks (Fig. 1). In each plot, 2 herbage samples were harvested to ground level within 2 randomly selected $1 \mathrm{~m}^{2}$ quadrates. The forage samples were oven dried at $50^{\circ} \mathrm{C}$ for 48 hours, and dry weights were recorded. Herbage samples, as well as hay and wheat-bran samples (Table 1), were analyzed for fat, crude protein, crude fiber and ash (AOAC 1990). Average daily forage and nutrient intake was calculated as the difference between pre-grazing and post-grazing forage mass divided by the number of ewe days of grazing in the paddock. Post-grazing forage mass was adjusted for the amount of growth during each period using estimates of pasture growth derived from cutting 16 randomly selected $1 \mathrm{~m}^{2}$ quadrates in adjacent ungrazed pasture at the beginning and the end of each grazing period. Pasture utilization efficiency (PUE) was calculated as the ratio of herbage intake to herbage availability.

Table 1. Chemical composition and nutritional value of the whole herbage, hay and wheat-bran.

\begin{tabular}{lccrr}
\hline \hline & \multicolumn{2}{c}{ Whole herbage } & \multirow{2}{*}{ Vetch/ oat hay } & \multirow{2}{*}{ Wheat-bran } \\
\cline { 2 - 3 } & Winter & Spring & & \\
\hline Dry matter (\%) & 23.1 & 21.0 & 83.4 & 89.2 \\
Crude protein (\% DM) & 15.1 & 17.7 & 12.8 & 17.6 \\
Fat, by ether extract (\% DM) & 2.8 & 3.5 & 1.2 & 3.7 \\
Crude fibre (\% DM) & 23.8 & 21.0 & 31.0 & 13.7 \\
Ash (\% DM) & 10.3 & 10.9 & 9.1 & 6.7 \\
N-free extract (\% DM) & 46.0 & 44.9 & 45.9 & 58.3 \\
Gross energy (MJ/kg DM) & $20.1^{\dagger}$ & $20.3^{\dagger}$ & $18.1^{\dagger}$ & $19.0^{\dagger \dagger}$ \\
\hline
\end{tabular}

$\dagger$ Evaluated according to the equation by Lanari et al. (1993). $\dagger \dagger$ Evaluated according to the equation by Schiemann et al. (1971). 
Table 2. Estimated dry matter (DM), crude protein (CP) and gross energy (GE) intake and pasture utilisation efficiency (PUE) for ewes in square and rectangular paddocks in winter and spring.

\begin{tabular}{|c|c|c|c|c|c|c|c|c|c|c|c|c|c|c|}
\hline \multirow[b]{3}{*}{ Parameters } & \multicolumn{6}{|c|}{ Winter } & \multirow{3}{*}{$\begin{array}{c}\text { SE } \\
\text { Herb. }\end{array}$} & \multicolumn{6}{|c|}{ Spring } & \multirow{3}{*}{$\begin{array}{c}\mathrm{SE} \\
\text { Herb. }\end{array}$} \\
\hline & \multicolumn{3}{|c|}{ Square paddocks } & \multicolumn{3}{|c|}{ Rectangular paddocks } & & \multicolumn{3}{|c|}{ Square paddocks } & \multicolumn{3}{|c|}{ Rectangular paddocks } & \\
\hline & Herb & Supp. & Total & Herb. & Supp. & Total & & Herb. & Supp. & Total & Herb. & Supp. & Total & \\
\hline DM intake (kg/ewe/day) & $0.77 \mathrm{a}$ & 1.06 & 1.83 & $0.68 b$ & 1.06 & 1.74 & 0.01 & $1.30 \mathrm{a}$ & 0.42 & 1.72 & $1.11 \mathrm{~b}$ & 0.42 & 1.53 & 0.01 \\
\hline $\mathrm{CP}$ intake (g/ewe/day) & $139 b$ & 146 & 285 & $121 b$ & 146 & 267 & 5.50 & $272 \mathrm{a}$ & 53 & 325 & $234 b$ & 53 & 288 & 2.61 \\
\hline GE intake (MJ/ewe/day) ${ }^{\dagger}$ & $19.4 \mathrm{~b}$ & 19.3 & 38.7 & $19.2 b$ & 19.3 & 38.5 & 0.09 & $21.1 \mathrm{a}$ & 7.5 & 28.6 & $20.6 b$ & 7.5 & 28.1 & 0.06 \\
\hline PUE $\quad(\%)$ & $58 \mathrm{~b}$ & & & $52 \mathrm{~b}$ & & & 1.54 & $67 \mathrm{a}$ & & & $58 \mathrm{~b}$ & & & 0.72 \\
\hline
\end{tabular}

$\dagger$ Evaluated according to the equation by Lanari et al. (1993). SE, standard error. For each season, means of pasture parameters within the same line followed by different letters are significantly different at $\mathrm{P}<0.05$

Herbage destruction index (HDI) was calculated as the ratio of herbage destroyed (i.e. covered by manure or trampled by sheep) to herbage available.

The grazing behavior of the ewes was recorded 3 times during each grazing period (on the $3^{\text {rd }}, 6^{\text {th }}$ and $9^{\text {th }}$ day) by 3 trained observers equipped with video cameras. Behavioral observations were conducted from 0900 to 1700 hour and were divided into $60 \mathrm{~min}$ periods for each group. A different focal animal was chosen at random every day in each group, and the $60 \mathrm{~min}$ observation periods were systematically rotated among treatments and replicates. Times spent eating, ruminating, standing inactive, resting, walking, defecating and urinating, exploring, and in other activities (self-grooming, grooming, scratching oneself, bleating, fencing biting) were recorded.

\section{Statistical Analysis}

Pasture and behavioral variables for each season were subjected to analysis of variance for repeated measures (SAS 1990), with shape of paddock as a nonrepeated factor and time and shape of paddock $x$ time as repeated factors. Pasture variables were also processed with paddock plot (boundary or middle) as source of variation. When significant effects were found, the Student T test was used to determine differences $(\mathrm{P}<0.05)$ between means.

\section{Results and Discussion}

The data on herbage intake and pasture utilization efficiency are reported in Table 2. The ewes in the rectangular paddocks had significantly smaller herbage intakes and lower pasture utilization efficiency both in the winter and in the spring. The shape of paddock did not significantly affect nutrient intakes in the winter, but protein and gross energy intakes were greater in the square paddocks than in the rectangular paddocks in the spring.

Herbage intake and pasture utilization efficiency were affected significantly by the interaction of paddock shape and plot location in a paddock. The amounts of herbage consumed by the square and rectangular paddock ewes were very similar in the middle of the paddocks, but the ewes in the rectangular paddocks had significantly smaller herbage intakes within the boundary plots (Table 3 ). This was caused by a greater amount of forage being destroyed and reduced pasture utilization in the boundary compared to middle plots (Fig. 1). The amount of herbage destroyed was $42 \%$ higher in the rectangular as compared to the square paddock boundary plots. Relative to the boundary length, the ewes in the rectangular paddocks destroyed proportionately less herbage than those in the square paddocks, but this is not surprising because the square paddock ewes had a $40 \%$ higher herbage intake and, consequently, a greater feces output with respect to the rectangular paddock ewes.

In both trials, grazing sheep spent a large part of the time (50 to $71 \%$ ) eating (Table 4). The ewes in the rectangular paddocks exhibited significantly lower eating times than those in the square paddocks both in the winter and in the spring. In contrast, the ewes in the rectangular paddocks walked and explored more than those in the square paddocks.

There is evidence that certain features within an environment may change the space available to inhabitants (Siegel and
Gross 1973) and corners or perimeters (i.e., shape) may vary the conceptual space of an area (Stricklin et al. 1979). It is well known that sheep spend a long time in exploring any new field they are put in and pay most initial attention to the field boundaries (Fraser and Broom 1990). In addition, settling down in a group along the field boundaries and corners has been described as a species-typical feature in sheep (Hutson 1984, Fraser and Broom 1990). Time spent in an area is proportional to the feces deposited by the sheep as they visit that area (Arnold 1981). Thus, taking into account that rectangular paddocks had $145 \%$ the perimeter of square paddocks, increased amount of forage destroyed by grazing ewes might be explained with some species-typical features of sheep, such as long-time walking, exploring and resting along the field boundaries, which are enhanced by higher perimeter to area ratio. In paddocks ranging from 70 to $900 \mathrm{~m}^{2}$ Ali and Sharrow (1994) found that the amount of forage destroyed by sheep is markedly higher during the early stages of grazing, decreases during the middle stages and often rises again in the later stages of grazing cycles. This suggests that higher amount of forage destroyed along boundary areas of rectangular paddocks might be primarily dependent on increased trampling by walking and exploring ewes during the early stages and on manure accumulation during the later stages of grazing periods. Increased

Table 3. Estimated herbage intake, pasture utilisation efficiency (PUE) and herbage destruction index (HDI) for ewes in square and rectangular paddocks in winter and spring.

\begin{tabular}{|c|c|c|c|c|c|}
\hline \multirow[b]{2}{*}{ Parameters } & \multicolumn{2}{|c|}{ Boundaries } & \multicolumn{2}{|c|}{ Middle } & \multirow[b]{2}{*}{ SE } \\
\hline & $\begin{array}{r}\text { Square } \\
\text { paddocks }\end{array}$ & $\begin{array}{c}\text { Rectangular } \\
\text { paddocks }\end{array}$ & $\begin{array}{c}\text { Square } \\
\text { paddocks }\end{array}$ & $\begin{array}{c}\text { Rectangular } \\
\text { paddocks }\end{array}$ & \\
\hline $\begin{array}{l}\text { Herbage allowance } \\
\text { (kg DM/ewe/day) } \\
\text { Herbage intake }\end{array}$ & 1.64 & 1.62 & 1.65 & 1.60 & 0.02 \\
\hline (kg DM/ewe/day) & $0.86 \mathrm{~b}$ & $0.60 \mathrm{c}$ & $1.21 \mathrm{a}$ & $1.19 \mathrm{a}$ & 0.01 \\
\hline PUE $\quad(\%)$ & $52 b$ & $37 \mathrm{c}$ & $73 a$ & $74 \mathrm{a}$ & 0.92 \\
\hline HDI & $26 b$ & $37 \mathrm{a}$ & $17 \mathrm{c}$ & $19 \mathrm{c}$ & 0.61 \\
\hline
\end{tabular}

Means within the same line followed by different letters are significantly different at $\mathrm{P}<0.05$. 
Table 4. Grazing behaviour of ewes in square and rectangular paddocks in winter and spring.

\begin{tabular}{|c|c|c|c|c|c|c|}
\hline \multirow[b]{2}{*}{ Parameters } & \multicolumn{2}{|c|}{ Winter } & \multirow[b]{2}{*}{ SE } & \multicolumn{2}{|c|}{ Spring } & \multirow[b]{2}{*}{ SE } \\
\hline & $\begin{array}{l}\text { Square } \\
\text { paddocks }\end{array}$ & $\begin{array}{c}\text { Rectangular } \\
\text { paddocks }\end{array}$ & & $\begin{array}{l}\text { Square } \\
\text { paddocks }\end{array}$ & $\begin{array}{c}\text { Rectangular } \\
\text { paddocks }\end{array}$ & \\
\hline \multicolumn{7}{|c|}{ (\% of total grazing time). } \\
\hline Eating & $58.6 \mathrm{a}$ & $49.6 b$ & 1.3 & $71.0 \mathrm{a}$ & $63.9 \mathrm{~b}$ & 1.4 \\
\hline Ruminating & 7.1 & 6.7 & 0.5 & 7.5 & 8.0 & 0.6 \\
\hline Standing & $3.5 b$ & $5.5 \mathrm{a}$ & 0.4 & $3.4 \mathrm{~b}$ & $5.0 \mathrm{a}$ & 0.3 \\
\hline Resting & 15.0 & 14.2 & 0.4 & 9.5 & 9.4 & 0.2 \\
\hline Walking & $6.9 \mathrm{~b}$ & $12.5 \mathrm{a}$ & 0.9 & $3.9 \mathrm{~b}$ & $6.7 \mathrm{a}$ & 0.7 \\
\hline Defecating+urinating & 2.1 & 1.6 & 0.6 & 1.3 & 1.1 & 0.5 \\
\hline Exploring & $3.7 b$ & $6.0 \mathrm{a}$ & 0.4 & $2.3 b$ & $4.4 \mathrm{a}$ & 0.3 \\
\hline Other activities & 3.1 & 3.9 & 0.9 & 1.1 & 1.5 & 0.5 \\
\hline
\end{tabular}

For each season, means within the same line followed by different letters are significantly different at $\mathrm{P}<0.05$.

amount of herbage destroyed can further enhance time spent in locomotion and exploration via the reduction in forage availability, which results in increased walking and exploring of the ewes searching for food (Gluesing and Balph 1980). This may explain why time spent in these activities was about $25 \%$ higher than the difference in perimeter between the rectangular and the square paddocks.

\section{Conclusions}

Although this study has little practical application for grazing management, due to small flock and paddocks used, it should be important to researchers who study voluntary feed intake or diet choice in sheep. Our findings suggest that the shape of pasture can affect the behavior and herbage intake of sheep grazing in small paddocks. This indicates that the choice of an appropriate paddock shape is required for research studies on sheep grazing behavior which generally uses small flocks and small paddocks. Under the conditions of this study, rectangular paddocks resulted in less efficient use of forage as compared to square paddocks and the greater amount of herbage destroyed along the paddock boundaries was primarily responsible for reduced intake of sheep in rectangular paddocks.

\section{Literature Cited}

Ali, E. and S.H. Sharrow. 1994. Sheep grazing efficiency and selectivity on Oregon hill pasture. J. Range Manage. 47:494-497.

Arnold, G.W. 1975. Herbage intake and grazing behavior in ewes of four breeds at different physiological states. Aust. J. Agr. Res. 26:1017-1024.

Arnold, G.W. 1981. Grazing behavior, 79-104. In: F.H.W. Morley (Ed.) Grazing animals. Elsevier Science Publishers. Amsterdam.

Arnold, G.W. and M.L. Dudzinski 1978. Ethology of Free Ranging Domestic Animals. Elsevier Scientific Publishers, Amsterdam.

Association of Official Analytical Chemists. 1990. Official Methods of Analysis, $15^{\text {th }}$ ed. AOAC, Arlington, Virg.

Bueno, L. and Y. Ruckebusch 1979. Ingestive behavior in sheep under field conditions. Appl. Anim. Ethol. 5:179-187.

Dudzinski, M.L. and G.W. Arnold 1979. Factors influencing the grazing behavior of sheep in a Mediterranean climate. Appl. Anim. Ethol. 5:125-144.

Fraser, A.F. and D.M. Broom. 1990. Farm animal behavior and welfare. Third edition. Bailliere Tindall. London. UK.

Gluesing, E.A. and Balph, D.F. 1980. An aspect of feeding behaviour and its importance to grazing systems. J. Range Manage. 33:426-427.

Hutson, G.D. 1984. Spacing behavior of sheep in pens. Appl. Anim. Behav. Sci. 12:111-119.
Lanari, D., E. Tibaldi, and E. D'Agaro. 1993. Equations for estimating gross energy ontent, organic matter digestibility and voluntary intake of various feedstuffs produced in Italy. Zootecnica e Nutizione Animale 19:57-71.

Lange, R.T. 1985. Spatial distributions of stocking intensity produced by sheep-flocks grazing Australian Chenopod shrublands. Transactions of the Royal Soc. of So. Australia 109:167-174.

Lynch, J.J. and D.A. Hedges. 1979. The influence of shape of paddock, type of fence and stocking rate on grazing behavior and social facilitation in Merino sheep. Appl. Anim. Ethol. 5: 321-331.

Olson, B.E., R.T. Wallander, V.M Thomas, and R. W. Kott 1996. Effects of previous experience on sheep grazing leafy spurge. Appl. Anim. Behav. Sci. 50:161-176.

Penning. P.D., A.J. Parsons, R.J. Orr, and G.E. Hooper 1994. Intake and behavior responses by sheep to changes in sward characteristics under rotational grazing. Grass and Forage Sci. 49:476-486.

Penning. P.D., A.J. Parsons, R.J. Orr, A. Harvey, and R.A. Champion 1995. Intake and behavior responses by sheep, in different physiological states, when grazing monocultures of grass or white clover. Appl. Anim. Behav. Sci. 45:63-78.

SAS Institute Inc. 1990. SAS User's Guide: Statistics, Version 6. SAS Institute Inc., Cary, N.C.

Schiemann R., W. Jentsch W., and Wittenburg, H. 1971. Zur Abhängigkeit der verdaulichkeit der Energie und Nührstoffe von der Höhe der Futteraufmahme und der Rations zusammentsetzung bei Milchkühen. Arch. Tierernähr. 21: 223-240.

Sevi, A., A. Muscio, and F. D'Emilio. 1996. Effect of pen-shape on behavior and space use of ewes, 15-18. Proceedings of the $12^{\text {th }}$ SIPAOC Meeting (Varese, 24-26 October 1996).

Siegel, P.B. and W.B. Gross. 1973. Confinement behavior and behavior with examples from poultry. J. Anim. Sci. 37: 612-617.

Stricklin W.R., H.B. Graves and L.L. Wilson. 1979. Some theoretical and observed relationships of fixed and portable spacing behavior of animals. Appl. Anim. Ethol. 5: 201-214. 